\title{
Looking Afresh at the French Roots of Continuous Easements in English Law
}

\author{
CIARA KENNEFICK
}

The thrill of comparative law is often the consequence of encounters with differences; the resulting frisson is equivalent to that experienced by readers of George Orwell's Nineteen Eighty-Four when, in the first line, they learn that '[i]t was a bright cold day in April, and the clocks were striking thirteen' and realise that the other world is governed by rules which are absent from or even inconceivable in their own. ${ }^{1}$ However, similarities, when unexpected, can be equally enthralling. The rule, now generally known as the rule in Wheeldon v. Burrows, ${ }^{2}$ which is the subject of this chapter, falls within the latter category. It is a rule which is familiar to anyone who has ever studied English law: approximately halfway through a course in land law, one learns that an easement (the principal type of servitude) which is 'continuous and apparent' may be created by implication when land which is in the hands of one owner is subsequently divided (by will, by contract or by deed). ${ }^{3}$ In Wheeldon v. Burrows itself, the question was whether an easement of light was born when the owner of a plot on which there was a building with windows sold the adjoining plot on which there was no building. One might retort that 'enthralling' is not the adjective which comes immediately to mind, having perused the foregoing sentences. Yet, behind an ostensibly dull and esoteric rule of English law is a colourful story of general significance to legal history and comparative law; ${ }^{4}$ at its heart is the remarkable migration to England of a thoroughly unremarkable French legal idea.

${ }^{1}$ G. Orwell, Nineteen Eighty-Four (London, 1949), 1.

${ }^{2}$ It is named after the eponymous case in the Court of Appeal which confirmed its status (and its limits); Wheeldon v. Burrows (1879) 12 Ch D 31. See the text from n. 32 to n. 33 and n. 57 to n. 60 .

3 Pheysey v. Vicary (1847) 16 M. \& W. 484; Borman v. Griffith [1930] 1 Ch 493.

4 There are important implications for (modern) English land law too, but they deserve a separate analysis in another forum. 
A common lawyer will find a strikingly similar rule in articles 688 to 694 of the French Civil Code, which have not been altered since they were promulgated under the auspices of Napoleon in $1804 .{ }^{5}$ The English and French rules are, prima facie, almost identical: the very same term, 'continuous and apparent', is found in both systems. Significantly, this similarity is entirely unexpected for two reasons. First, while French ideas influenced the development of many aspects of English private law in the nineteenth century, ${ }^{6}$ land law was, generally, exempt from this phenomenon. ${ }^{7}$ Secondly, while it has been said, justifiably, that 'the law of easements [is] perhaps the most Roman part of English law', ${ }^{8}$ the rule which is the subject of this chapter is authentically French; it is not derived from Roman law.

This study recounts the remarkable story of a particular legal transplant: it examines the origins in French law, the donor system, of the rule on the creation of 'continuous and apparent' easements by implication; its transplantation 9 into English law, the donee system; and its fate thereafter in both systems. One part of this story has been told before. Over half a century ago, Brian Simpson published a landmark article on this subject; he described his contribution as 'a cautionary tale,

${ }^{5}$ Lewison LJ refers to articles 688 and 689 in Wood v. Waddington [2015] EWCA Civ 538, [15], but these provisions simply define the concepts; the subsequent provisions embed these concepts in the rule on the creation of servitudes by implication.

${ }^{6}$ On contract law, see A. W. B. Simpson, 'Innovation in Nineteenth Century Contract Law', Law Quarterly Review, 91 (1975), 247-78. Simpson's article highlights only a part of this phenomenon. As discussed in the text (from n. 67 to n. 70), the views of J.-M. Pardessus appear in English cases on easements, bills of exchange and shipping. Furthermore, the very frequent citation of B.-M. Emerigon and R.-J. Valin in English cases on shipping is especially striking.

${ }^{7}$ French land law was not entirely ignored in England, however. The provisions on this subject in the French Civil Code featured in the great political and legal debate in England on the merits of codification and the reform of land law in the early nineteenth century: see J. Humphreys, Observations on the Actual State of the English Laws of Real Property: With the Outlines of a Code (London, 1826). On the influence of the Civil Code more generally on the reform of English land law, see the text from n. 106 to n. 107.

8 B. Nicholas, An Introduction to Roman Law, 2nd edn (Oxford, 1975), 148.

9 Metaphors are especially conspicuous in comparative law. In this chapter, I consciously use the metaphor of transplantation to describe the movement of a legal idea from French law to English law. It is particularly apt here since, as explained in the section next but one, the French legal idea which is the subject of this chapter was deliberately adopted in, and so, figuratively, transplanted into, England. Furthermore, the presence in England of this legal idea was not ephemeral; as is evident in this chapter, it is still extant and, so, figuratively, embedded in English law. 
containing several morals'. ${ }^{10}$ Simpson's article was short - not even eight pages - and he used only English sources. ${ }^{11}$ I argue here that many other 'morals' emerge from a deeper historical and comparative analysis of this reception, all of which are encapsulated in the central thesis, namely, that in the middle of the nineteenth century English lawyers adopted a French rule, oblivious, then as now, to the fact that it had already been recognised in France as profoundly problematic.

\section{Introduction}

A mere cursory perusal of the French rule on 'continuous and apparent' servitudes in the French Civil Code reveals a problem which contains two parts. The first is that articles 692 and 694 flatly contradict each other. Article 692 provides that only servitudes which are 'continuous and apparent' may be created by implication when land is divided, whereas article 694 says that a 'visible sign' and so only the apparent nature of the servitude are sufficient for this purpose. The second part of the problem concerns the categories of 'continuous' and 'discontinuous'. The term 'continuous' is defined in article 688: such servitudes can be exercised 'without needing an act of man', and drains and rights to light are given as two examples. ${ }^{12}$ Article 688 also provides that 'discontinuous' is simply the antonym of 'continuous': a right of way is listed therein as one manifestation of a discontinuous servitude. When reading these provisions for the first time, one wonders why 'continuous' servitudes so defined are, according to article 692, given special treatment in the rule on the creation of servitudes by implication. The term 'continuous' is so firmly established in French law and in English law that this question has, in the past two centuries, been posed only once, in an unofficial but authoritative proposal for the reform of the law of property in France. ${ }^{13}$ Yet retracing one's mental steps and rereading the relevant provisions

10 A. W. B. Simpson, 'The Rule in Wheeldon v. Burrows and the Code Civil', Law Quarterly Review, 83 (1967), 240-7, at 240.

11 Simpson explains that he was not 'able to consult' a particular French treatise, but it is notable that no other French materials are cited either; ibid., 246.

12 This translation is mine, as are all other translations from French into English in this chapter.

13 See below, 194. Curiously, in its study of servitudes in 2011, the English Law Commission engaged in no critical analysis of the distinction between continuous and discontinuous easements; Law Commission, 'Making Land Work: Easements, Covenants and Profits à Prendre' (Law Com N 327, 2011). 
again in search of the purpose underlying the distinction between continuous and discontinuous servitudes are of no avail; these categories seem to be devoid of any objective, still less a rational one. ${ }^{14}$ How, then, can we account not only for the existence of the rule on the implication of servitudes in French law but also for its transplantation into and survival in English law?

This chapter focuses only on the adjective 'continuous'. ${ }^{15}$ Its companion 'apparent' is equally significant in theory and in practice but the implications of this adjective are, principally, of interest to land lawyers: ${ }^{16}$ the comparative lawyer and the legal historian may, therefore, pass them by with relative equanimity. The category of 'continuous' servitudes is, and always has been, a very problematic feature of English law: as we shall see in the following section, this concept has no stable meaning. One might be tempted to argue that it is then a failed transplant, a manifestation of what Gunther Teubner famously described as a 'legal irritant', a rule which is unsuitable simply because of its foreign origin. ${ }^{17}$ It falls, after all, within the law of property, which, often and in various systems, has been considered to comprise material intrinsically unsuitable for transplantation or even for a comparative study of a purely speculative kind. ${ }^{18}$ This chapter demonstrates that such a conclusion would be wrong. A deeper analysis of a comparative and historical nature reveals that the concept of 'continuous' servitudes is, and always has

${ }^{14}$ Indeed, it has been said that this distinction was transmitted to India 'more as a convenient method of classification than as a means of supplying a logical and practical division of the subject'; F. Peacock, The Law Relating to Easements in British India, vol. I (Calcutta, 1904), 19 (my emphasis). I am grateful to Professor Raymond Cocks for encouraging me to look at this treatise.

15 The concept of a continuous easement transcends the boundaries of the rule which is the subject of this chapter. There are, therefore, two other reasons for which it is important to understand fully the history of the term 'continuous'. First, even though the adjective 'continuous' is not mentioned in section 62 of the Law of Property Act 1925 or in the text of its predecessor, section 6 of the Conveyancing Act 1881, it has been held that only continuous easements can be created in certain circumstances on this statutory basis. This is a controversial question, outside the scope of this chapter; the latest development is Wood v. Waddington [2015] EWCA Civ 538. Secondly, the term continuous may be used to describe an easement in an express grant. See, for example, Wood v. Waddington [2015] EWCA Civ 538, [12].

${ }^{16}$ I intend to examine this aspect of the rule in a future article. In contrast to 'continuous', 'apparency' has not been controversial in either England or France.

17 G. Teubner, 'Legal Irritants: Good Faith in British Law or How Unifying Law Ends up in New Divergences', Modern Law Review, 61 (1988), 11-32.

18 On the latter, see S. Van Erp, 'Comparative Property Law', in M. Reimann and R. Zimmermann (eds.), Oxford Handbook of Comparative Law, 2nd edn (Oxford, 2019), 1031-57. 
been, a problematic feature of French law too. The rule which is the subject of this chapter was, therefore, dysfunctional ${ }^{19}$ from its very inception. This finding raises two particularly salient questions. First, why was the contemporary French dimension overlooked in English law when the rule was imported and subsequently developed? Secondly, when, why and how did English law move away from what Lewison LJ has recently called the 'rigid' definition of 'continuous' in the French Civil Code? ${ }^{20}$ Answers to these questions are long overdue; after all, almost a century and a half has passed since Wheeldon v. Burrows decisively enshrined the rule on 'continuous' easements in English law. ${ }^{21}$

\section{The Reception of the French Rule in England}

The French rule on the creation of continuous servitudes by implication was planted in English soil in $1839^{22}$ when Charles Gale incorporated it into the first edition of what became a famous treatise on easements. ${ }^{23}$ Holdsworth described it as a 'pioneer treatise' since ' $[0] \mathrm{n}$ this subject

19 The use of this term is explained in the penultimate section.

20 Wood v. Waddington [2015] EWCA Civ 538, [15].

21 (1879) 12 Ch D 31, 48-60.

22 The French term 'continuous' (translated as 'continual' and 'continuable') and its antonym had been mentioned ten years earlier by Charles Purton Cooper, 'a lawyer and antiquary' (J. A. Hamilton, rev. B. F. Wood, 'Cooper, Charles Purton (1793-1873)', in Oxford Dictionary of National Biography (Oxford, 2004), available at https://doi.org/10 .1093/ref:odnb/6213), in his evidence to the Royal Commission on Real Property, which had been established partly as a result of the publication of Humphreys's text (on which see n. 7): Copy of the First Report Made to His Majesty by the Commissioners Appointed to Inquire into the Law of England Respecting Real Property (London, 1829), 136. However, the context of this discussion was prescription rather than the creation of easements by implication. In French law, these categories are used in prescription too. See articles 690 and 691 of the Civil Code.

23 C. J. Gale and T. D. Whatley, A Treatise on the Law of Easements (London, 1839), 16, 47-54. Gale, a barrister of the Middle Temple, produced some of the named law reports and 'from 1846, or soon after the passing of the County Courts Act of that year, until about 1874, was a judge of county courts in the Southampton district'; M. Bowles, Gale on Easements, 13th edn (London, 1959), vii. Whatley, also a barrister of the Middle Temple, 'practised as an equity draftsman and conveyancer'; he does not appear in any subsequent edition of this treatise, and with respect to the first' ' $\mathrm{t}$ ] he extent of his collaboration is not known'; ibid. The treatise is, generally, ascribed to Gale only. Further details on Gale and Whatley can be found in a note by E. Peters in J. Gaunt and P. Morgan, Gale on Easements, 19th edn (London, 2012), ix-xv. 
there was very little English authority in $1839^{\prime} .^{24}$ Gale was, consequently, able to shape much of this area of English law by drawing principally on Roman and, notably for our purposes, French sources. His influence may be measured by the numerous cases on this rule in which his treatise (including subsequent editions thereof, edited by others) is cited: in the formative period between the publication of the first edition in 1839 and the seminal decision of Wheeldon v. Burrows four decades later, there are, at least, twelve such instances. ${ }^{25}$

Nonetheless, it is notable that Gale did not obsequiously copy French law in every respect when composing his treatise. Just before embarking on a discussion of the rule on 'continuous and apparent' easements, he emphatically rejected the distinction between rustic and urban servitudes, a legacy of Roman law, which is found in article 687 of the French Civil Code: he declared that it was not a 'practically useful distinction in the English law'. ${ }^{26}$ While in Roman law certain consequences flowed from the classification of servitudes as rustic or urban, ${ }^{27}$ this distinction was, actually, entirely otiose in French law when, in 1839, Gale's treatise was published. Indeed, in 1811, a mere seven years after the promulgation of the French Civil Code, Charles-Bonaventure-Marie Toullier, the author of a leading treatise, concluded that the distinction was 'of almost no use in practice'. ${ }^{28}$ This is a withering assessment given that Toullier was writing in the exegetical tradition of reconciling and finding a rational purpose for every article in the French Civil Code; the adverb 'almost' appears simply to be a concession to the decorum of legal discourse as no

${ }^{24}$ W. S. Holdsworth, A History of English Law, vol. 15, eds. A. L. Goodhart and H. G. Hanbury (London, 1965), 295.

25 Pheysey v. Vicary (1847) 16 M. \& W. 484, 488-9 (counsel); Pyer v. Carter (1857) 1 H. \& N. 916, 918-19 (counsel); 922 (Watson B); Worthington v. Gimson (1860) 2 E. \& E. 618, 234 (counsel); 234, 235 (Crompton J); Pearson v. Spencer (1861) 1 B. \& S. 571, 579 (counsel); Pearson v. Spencer (1863) 3 B. \& S. 761, 762 (counsel); Dodd v. Burchell (1862) 1 H. \& C. 113, 117 (counsel), 121 (Martin B); Hall v. Lund (1863) 1 H. \& N. 676, 681-2 (counsel); Polden v. Bastard (1863) 4 B. \& S. 258, 263-4 (Crompton J); Polden v. Bastard (1865) L.R. 1 Q.B. 156, 159 (counsel); Suffield v. Brown (1864) 4 De G. J. \& S. 185, 189 (counsel for both parties), passim (Lord Westbury LC); Crossley \& Sons Ltd v Lightowler (1866) L. R. 3 Eq. 279, 282-3 (counsel), 293 (Sir W. Page Wood V.C.); Watts v Kelson (1871) LR 6 Ch App 166, 172 (counsel).

${ }^{26}$ Gale and Whatley, Easements, 17.

27 W. W. Buckland, A Text-Book of Roman Law from Augustus to Justinian, 2nd edn (Cambridge, 1950), 262-8.

28 C.-B.-M. Toullier, Le droit civil français, suivant l'ordre du Code Napoléon, vol. III (Rennes, 1811), 507. Significantly, the principle underlying the distinction was 'uncertain' even in Roman law: Buckland, Text-Book of Roman Law, 262. 
use of any kind is even conceivable. Puzzlingly, the drafters of the Civil Code had overlooked the latter point entirely. ${ }^{29}$

While Gale had, therefore, exercised discernment in his discussion of rustic and urban servitudes, no such critical appraisal is evident in his discussion of the rule on continuous servitudes. There is no explanation of the purpose of the distinction between continuous and discontinuous easements and, in contrast to rustic and urban servitudes, Gale fails to consider whether the former categories are of any use in English law. Gale clearly had some affection for the French rule. He gave it prominence in the preface and devoted a substantial number of pages to it in a subsequent chapter. As Simpson notes, Gale 'seems to have been rather excited by the idea' that both the French rule and its English offshoot were based on pre-Revolutionary French law. ${ }^{30}$ However, Gale's unsubstantiated claim in this respect ${ }^{31}$ is not correct. As demonstrated in the following section of this chapter, this rule did not exist in France before the promulgation of the Civil Code in 1804. Furthermore, as Lord Blackburn observed, the distinction between continuous and discontinuous easements 'certainly is not to be found in any English law authority before Gale on Easements in 1839'. ${ }^{32}$ The absence of any critical appraisal of the utility of this distinction may be the consequence of these emotions. However, Simpson too may have got carried away with his excitement for this topic: he thought that following the seminal case of

29

Unsurprisingly, a search of the database www.legifrance.gouv.fr reveals that servitudes have been described as rustic or urban in only two cases: Lyon, 19 May $2009 \mathrm{n}^{\circ}$ 08/00797 ('rustic servitude'); Cass civ 3, 25 October 1983 n 81-15530 ('urban servitude'). For another (but, arguably, less egregious) example of Roman law being unthinkingly reproduced in the French Civil Code in 1804 and in the reformed text in 2016, see C. Kennefick, 'Violence in the Reformed Napoleonic Code: The Surprising Survival of Third Parties', in J. Cartwright and S. Whittaker (eds.), The Code Napoléon Rewritten: French Contract Law after the 2016 Reforms (Oxford, 2017), 109-33.

30 Simpson, 'Wheeldon v. Burrows and the Code Civil', 242-3.

31 No evidence is provided but in one passage the claim is qualified by the adjective 'probably'; Gale and Whatley, Easements, vi, 52. The statement that both rules are derived from 'ancient French law' (ibid., 52) was omitted from the sixth edition which was published in 1888, and it did not resurface in other editions; nonetheless, the claim survives in Gale's original preface which has appeared in every edition since the treatise was first published in 1839. Intriguingly, a similar claim, also without any evidence, was made in a French thesis in 1885; J. Latreille, De la destination du père de famille (Paris, 1885), 313-18. There is no reference to Gale in Latreille's study.

32 Dalton v. Angus (1881) 6 App. Cas. 740, 821. His comment is made in the context of prescription, but it does not appear to exclude the use of these categories in the rule on the creation of servitudes by implication. 
Wheeldon v. Burrows in which the Court of Appeal held that the rule did not apply when the grantor - as opposed to the grantee - sought to create an easement by implication, the French rule was 'deprived thereby of its raison d'être in the common law'. ${ }^{33}$ However, as the following section demonstrates, the rule never had a purpose in French law either.

The subsequent application of the rule on the creation of continuous easements by implication indicates that there has never been a stable interpretation of the categories of continuous and discontinuous easements in English law. ${ }^{34}$ Sometimes the original - i.e. the French and, thus, Gale's - meaning is correctly understood. ${ }^{35}$ One notable example is Pearson v. Spencer, where the creation of a right of way was expressly rejected on this basis: Blackburn J stated that 'there is a distinction between continuous easements, such as drains, \&c., and discontinuous easements, such as a right of way. ${ }^{36}$

In other cases, the original meaning is misunderstood or overlooked, and an interpretation which differs from the original is proffered. ${ }^{37}$ The judicial seeds appear to have been sown in Pearson v. Spencer in 1863 when Wilde B interrupted counsel's argument to declare that '[a] path through a man's field may not be used once in six months, but a gravelled path up to his house may be used forty times in a day. On the other hand, a drain may be used only occasionally. ${ }^{38}$ The full story of the emergence of this indigenous (mis)interpretation will be recounted in the next section but one of this chapter. For now, it suffices to note that, since then, the term continuous has frequently been (mis)used to describe easements which are used often, and those which are used intermittently have been (mis)described as discontinuous. This new paradigm, which some judges considered to be the only one, generated an alternative (albeit bizarre) reason for the exclusion of rights of way from the rule

33 Simpson, 'Wheeldon v. Burrows and the Code Civil', 244.

${ }^{34}$ Moreover, the field in which they operate has never been stable: see n. 17.

35 Even then, there is, of course, room for dispute about whether certain easements need 'an act of man' and are, thus, discontinuous within the meaning of article 688 of the Civil Code. In French law, see, e.g. J.-L. Bergel, M. Bruschi and S. Cimamonti, Traité de droit civil: les biens, 2nd edn (Paris, 2010), 379-80.

${ }^{36}$ (1861) 1 B. \& S. 571, 583. The right of way was, however, created on the separate ground of necessity. Another clear example is Pyer v. Carter (1857) 1 H. \& N. 916, 921-2 (Watson B). See too Dalton v. Angus where (the then) Lord Blackburn again correctly outlined the distinction albeit in the different context of prescription: (1881) 6 App. Cas. 740, 821.

37 See e.g. Polden v. Bastard (1865) LR 1 QB 156, 161 (Erle CJ); Taws v. Knowles [1891] 2 QB 564, 568, 570 (A. L. Smith J).

38 Pearson v. Spencer (1863) 3 B. \& S. 761, 762-3. 
on the creation of easements by implication. In 1884, Chitty J, for example, affirmed that 'a right of way ... is a discontinuous easement ... because a man is not always walking in and out of his front door. ${ }^{39}$ It is almost as if the French exegetical tradition, which encourages the pursuit of a rational and coherent explanation for every rule, was flowering in England just as it was wilting in France. ${ }^{40}$

Once this new (mis)interpretation of these terms spread, other truly discontinuous rights inevitably came to be classified as continuous by judges, who appeared to be oblivious to the fact that they were not actually continuous at all. Accordingly, in a case in which the claimant argued that an easement to discharge refuse into a stream had been created by implication, Channell B stated that '[i]n order to be continuous, the user need not be on every day in the week; and there was clearly a continuous user when the refuse was discharged into the stream, on an average, seven times a fortnight'. ${ }^{41}$ The (mis)interpretation was still apparent almost a century later, when Ungoed-Thomas J declared that 'there has certainly been continuous user, in the sense the right has been in fact used whenever the need arose'. ${ }^{42}$

In 1916, it was said that 'the distinction between continuous and noncontinuous easements has ... been considerably modified in favour of implying grants on severance even of non-continuous easements under special circumstances', ${ }^{43}$ the special circumstances being that the right was used continuously, and as demonstrated in the previous paragraph, that could almost always be said to be the case and so the category became, effectively, meaningless. Therefore, there were also cases in which the original meaning was understood but then consciously disregarded. In Brown v. Alabaster, for example, Kay J stated that the right of way in issue in that case 'may pass, although in some sense it is not an apparent and continuous easement; or rather, may pass - because, being a formed road, it is considered by the authorities, in cases like this, to be a

39 Bayley v. Great Western Railway Company (1884) 26 Ch D 434, 442.

40 This tradition was in decline from 1880: J. Ghestin, G. Goubeaux and M. Fabre-Magnan, Traité de droit civil: introduction générale, 4th edn (Paris, 1994), 115.

41 Hall v. Lund (1863) 1 H. \& N. 676, 685.

42 Ward v. Kirkland [1967] Ch 194, 225. Lewison LJ's description of this use of the term continuous as 'very unorthodox' in Wood v. Waddington [2015] EWCA Civ 538, [15], does not undermine the point in this paragraph since he was considering a different issue.

43 Schwann v. Cotton [1916] 2 Ch 120, 128 (Astbury J). 
continuous and apparent easement - by implied grant'. ${ }^{44}$ Strikingly, the terms continuous and discontinuous could thus be understood in the original French sense or (mis)understood in the new indigenously English sense: the conclusion would be the same in either case.

English law has, therefore, as Lewison LJ recently remarked, 'moved away from the rigid distinction in the French Code Civil'. ${ }^{45}$ However, as the analysis in this section indicates, the terms continuous and discontinuous now appear to be otiose in England. They survive as labels which every student of law learns and many lawyers and judges invoke, but no case turns any more on their interpretation or (mis)interpretation. Indeed, this may be true of English law for, at least, the last ninety-one years. ${ }^{46}$

\section{The Origins and Contemporary Fortunes in France of the Rule}

An examination of the French dimension yields three points of significance. First, the roots of the rule on continuous servitudes are not very deep. Its appearance in the final version of the Civil Code was a surprise since it was not mentioned in any of the three drafts which had been composed during the Revolutionary period. ${ }^{47}$ Furthermore, it does not appear in the pre-Revolutionary law: where servitudes could be created by implication - essentially in the pays de droit coutumier, areas north of the Loire - it was not a requirement. ${ }^{48}$ Gale claimed that the Civil Code

44 (1887) 37 Ch D 490, 507. See too Thomas v. Owen (1888) 20 QBD 225, 229 (Fry LJ); Borman v. Griffith [1930] 1 Ch 493, 499 (Maugham J).

45 Wood v. Waddington [2015] EWCA Civ 538, [15].

${ }^{46}$ E. P. Hewitt and M. R. C. Overton, Dart's Treatise on the Law and Practice Relating to Vendors and Purchasers of Real Estate, vol. I, 8th edn (London, 1929), 489.

47 P.-A. Fenet, Recueil complet des travaux préparatoires du Code civil, vol. I (Paris, 1827), $45,117-18,251$.

48 The distinction between continuous and discontinuous servitudes may have been used long before 1804 in the different context of the creation of servitudes by prescription; P.A. Merlin, Répertoire universel et raisonné de jurisprudence, vol. XXXI, 5th edn (Paris, 1828), 82-83. This is, of course, also the position in French law today. The distinction is certainly not Roman. Merlin ascribed it to Caepolla, a fifteenth-century jurist; ibid., 83. In contrast, Lord Blackburn stated that it was 'perfectly new; for though the difference between the things must always have existed, [he could not] find any trace of the distinction having been taken in the old French law'; Dalton v. Angus (1881) 6 App. Cas. 740, 821. It is not necessary, for the purposes of this study to resolve this debate in the context of prescription. The argument that the creation of servitudes by implication was not restricted to continuous servitudes before 1804 is substantiated in the text from n. 46 to $n$. 51 . 
'merely recognised an ancient provision of the French law' and cited Robert-Joseph Pothier as authority for this proposition. ${ }^{49}$ However, the terms 'continuous' and 'discontinuous' are entirely absent from Pothier's discussion of the creation of servitudes by implication; ${ }^{50}$ in fact, there is no trace in his writings of the idea that only certain types of servitudes could be created in this way.

The second point of significance is that the problematic nature of the rule had been identified in France before 1839, when Gale's treatise was first published. From at least 1832, there were numerous conflicting decisions on whether discontinuous servitudes were excluded. ${ }^{51}$ This uncertainty was the predictable consequence of the apparent conflict between articles 692 and 694 of the Civil Code: as we have already seen, the former, unlike the latter, appeared to exclude discontinuous servitudes from the rule on the creation of servitudes by implication. Significantly, this problem was discussed at the time in great detail in leading treatises, notably those which were composed by Toullier and Alexandre Duranton. ${ }^{52}$

Furthermore, it is important to note that this debate continued long after 1839. The question was described as 'one of the thorniest' in the law of servitudes and as 'really difficult' in commentaries on two separate cases published in 1840 and 1854 respectively. ${ }^{53}$ It is clear that much intellectual energy was devoted to resolving the problem: as noted in a thesis published in 1885, more than 'seven theories' had been developed. ${ }^{54}$ In 1863 , a landmark decision of the Cour de cassation, the highest civil court in France, resolved the matter by adopting one of these theories: it held that discontinuous servitudes may be created by implication if the division of the land occurred in writing and there was no

49 Gale and Whatley, Easements, 52.

${ }^{50}$ R.-J. Pothier, Coutumes des duché, bailliage et prévôté d'Orléans et ressort d'iceux (Paris and Orléans, 1780), 398.

${ }^{51}$ Before 1839, the argument that discontinuous servitudes could not be created by implication had been rejected in several cases: see, e.g. Toulouse, 21 July 1836: S.37.2.155 and in the Cour de cassation, Cass 26 April 1837: S.37.1.916. This argument was, however, accepted in other cases: e.g. Lyon, 11 June 1831: S.32.2.123; Paris, 21 April 1837: footnote in S.37.1.916, 917.

52 Toullier, Droit civil français, 524-30; A. Duranton, Cours de droit français suivant le Code civil, vol. V (Paris, 1827), 576-84.

${ }^{53}$ Cass 24 February 1840: S.40.1.97, 97 (anonymous author); Cass civ 30 November 1853: S.1854.1.679, 679 (anonymous author).

${ }^{54}$ Latreille, La destination du père de famille, 10. 
clause expressly excluding the servitude. ${ }^{55}$ As writing is either required or almost systematically used in practice when land is divided, the exclusion of discontinuous servitudes has, thus, been heavily circumscribed: most servitudes which can be exercised 'without needing an act of man' are now capable of being created by implication.

Thus, like English law, French law was transformed in response to a clear desire to circumvent the rule on continuous servitudes. As explained in the preceding section, the meaning of 'continuous' was altered in English law in order to achieve this end. However, a different course was taken in France, as we have just seen. French courts decided to give precedence to a provision, article 694, which does not require the servitude to be continuous by greatly restricting the scope of another, article 692, which contains this very condition.

All these developments in French law were happening contemporaneously with the struggles in English law. Why did English law adopt one of the most problematic features of the French law of property, a body of rules which was described in 2008 by a large and important group of French scholars as 'not, by a long way, the best' part of the Civil Code $?^{56}$ Given the affection of the French for their Code, this is, really, a firm denunciation. Indeed, these scholars concluded that the rule on continuous servitudes was 'really of no practical use today'. ${ }^{57}$ As demonstrated in this chapter, there is, in fact, no moment in time at which it was ever of practical use in France.

\section{Overlooking the Contemporary Debate in France: An English Omission}

One might legitimately wonder why this controversy was overlooked in England in 1839 and thereafter. After all, counsel and judges who sought to undermine the rule on continuous easements could have used this information to alter the rule earlier or even remove it altogether. This hypothesis is certainly not inconceivable. Indeed, a focus on the French

55 Cass req 7 April 1863: S 63.1.369. There is also a second reason for which this decision is a landmark. It was held that this rule applied to all modes of dividing land and was not restricted to 'contract' as article 694 suggests. This is also the position in English law; see the text from n. 1 to n. 2 .

56 Proposition de réforme du livre II du Code civil relatif aux biens (which is known as the 'Avant-projet Capitant de réforme du droit des biens'), 3: www.henricapitant.org/storage/ app/media/pdfs/travaux/Avant-projet_de_reforme_du_droit_des_biens_19_11_08.pdf.

57 Ibid., 3, 12. 
roots of the part of the English rule which allowed an easement to be reserved in favour of the grantor helped to hasten its demise: Lord Westbury LC's observation in Suffield v. Brown that this part of the English rule was based on 'a mere fanciful analogy' with the French rule ${ }^{58}$ was invoked by counsel in Wheeldon v. Burrows, the case which, as noted above, ${ }^{59}$ excised this feature from the English rule. Two factors may explain why the contemporary debate in France was not known or used in legal discourse in England: first, there was a fateful focus in Gale's treatise on one particular French author, Jean-Marie Pardessus, who ignored the debate entirely; secondly, Gale's treatise was treated with such respect by those who edited subsequent editions and by judges and counsel that it may have seemed unnecessary to look elsewhere.

Pardessus, a contemporary French jurist, was cited liberally by Gale in the first edition of his treatise which was published in 1839. Indeed, Pardessus survived as a central feature of this treatise until the editor of the thirteenth edition decided, in 1959 , to expunge him from the text. ${ }^{60}$ Significantly, Pardessus did not mention the fact that the rule on continuous servitudes was controversial. He simply outlined his own theory of how the conflict between the relevant provisions in the Civil Code could be resolved. ${ }^{61}$ Remarkably, while several contemporary cases are cited in his discussion, none addresses the tension between 692 and $694 .{ }^{62}$ Yet, as noted above, from 1832 a series of (conflicting) decisions engaged directly with this very point.

In contrast, two of Pardessus's contemporaries in France discussed this debate in great detail before the cases on this point even began to emerge. In 1809, Toullier discussed several angles before concluding that 'we will have to wait for the courts to determine the true meaning of [article 694]' and its relationship with article $692 . .^{63}$ Similarly, in 1827, Duranton highlighted the fact that articles 692 and 694 raised 'some difficulties',

58 (1864) 4 De G. J. \& S. 185, 195.

59 See the text from n. 37 to n. 39.

60 Bowles, Gale on Easements, ix.

61 J.-M. Pardessus, Traité des servitudes ou services fonciers, vol. II, 8th edn (Paris, 1838), 121, 139-42. Pardessus produced several editions of this treatise, and it is not clear which edition Gale used. The decision to use the 1838 edition in this chapter is deliberate: this edition is, prima facie, least likely to be advantageous to the argument as the cases on the rule which begin in 1832 are more likely to feature therein than in previous editions.

62 Ibid., 139, 142.

63 Toullier, Droit civil français, 528. 
and he then outlined and assessed some views on how they could be resolved. ${ }^{64}$

Yet Gale focused almost exclusively on Pardessus. Only two other French writers, Pothier and Philippe-Antoine Merlin, are invoked and neither would have alerted Gale to this problem. Pothier was writing long before 1804 and, as noted in the foregoing section, there is nothing in his extensive oeuvre to support the idea that discontinuous servitudes ought to be excluded from the rule on the creation of servitudes by implication. ${ }^{65}$ Merlin, who is cited in the second edition of Gale's treatise in 1849 but not in the context of this rule, is, in contrast to Pothier, a contemporary of Gale. Nonetheless, including Merlin's views on this point would not have been very illuminating since he simply notes the 'difference' between articles 692 and $694 .{ }^{66}$

Gale's decision to focus principally on Pardessus seems, at first sight, to have been sensible. Pardessus was a leading authority in France at the time. He was also held in high esteem in England and not only by Gale, who described him as 'an eminent French writer on servitudes ${ }^{67}$ Even before Gale's treatise first appeared in 1839, Pardessus had been described by counsel as a 'writer of authority' in a case on easements. ${ }^{68}$ Indeed, in the different context of bills of exchange, Pardessus's views had been cited by Joseph Chitty as early as 1818 in the fifth edition of his treatise on that subject. ${ }^{69}$ Subsequent to this letter of introduction from Chitty, Pardessus was regularly invoked by counsel and judges in English cases on bills of exchange and shipping. ${ }^{70}$ Therefore, Gale's reliance on Pardessus may have added weight and even lustre to the former's observations on the English law of easements. Nonetheless, it is likely that Gale's neglect of other sources led him to overlook the debate in France, in courts and amongst scholars, on the exclusion of discontinuous easements from the rule on the creation of servitudes by implication.

64

65

66 Merlin, Répertoire de jurisprudence, 76. It is clear that Gale was using this edition (see n. 46 for the details) of Merlin's work.

67 Gale and Whatley, Easements, vii.

68 Peyton v. The Mayor and Commonalty of London (1829) 9 B. \& C. 725, 732.

69 J. Chitty, A Practical Treatise on Bills of Exchange, Checks on Bankers, Promissory Notes, Bankers' Cash Notes, and Bank Notes, 5th edn (London, 1818) 76, 78, 83.

70 Restricting the list to cases before 1839, see, e.g. Cox v. Troy (1822) 5 B. \& Ald. 474, 476 (Chitty, counsel for the claimant, cited Pardessus in argument), 481 (Best J); Mitchell v. Darthez (1836) 2 Bing. N. C. 555, 562 (counsel); Gould v. Oliver (1837) 4 Bing. N. C. 134, 139 (counsel); Shipton v. Thornton (1838) 9 A. \& E. 314, 335 (Lord Denman CJ). 
The second question which needs to be addressed is why other French sources which would have revealed the problem with the French rule were, seemingly, overlooked by others. The remarkable respect which judges had for Gale's treatise is a possible explanation. In 1847, Parke $B$ described Gale's treatise as 'a very good one ${ }^{, 71}$ and eighteen years later Lord Westbury LC described Gale as '[a] learned and ingenious author' who had produced a 'work of great merit. ${ }^{72}$ Such esteem for scholarly work was, of course, not unprecedented, especially in land law: in 1854, Lord Campbell told the House of Lords that the works of Edward Sugden (Lord St Leonards) 'answered all the purposes of a code'. ${ }^{73}$ Nonetheless, it is significant that Gale was one of only a few writers on whom accolades were bestowed so markedly in court. Furthermore, it seems that the editions of this treatise which were produced by legal minds other than Gale's were able to bask in the glow of the reputation earned by Gale. ${ }^{74}$

Gale is not exclusively to blame for failing to notice the controversy in France, of course; the editors who took over his treatise from 1862 and the judges and counsel in the cases failed to engage with alternative French sources which would have revealed that the rule in France was plagued by a similar problem. French sources on the Civil Code other than Pardessus were certainly not unknown to English lawyers at this time. Significantly, Toullier and Duranton, two eminent writers who, as explained in this section, had engaged in detailed discussion of the controversy surrounding the rule on continuous servitudes, were cited in English cases in the 1860s, and one of these cases was even on easements. ${ }^{75}$ Had the discussions in these treatises relating to the rule on continuous servitudes been consulted by someone learned in English law, the problems with the French rule and their implications for its English progeny would have been immediately obvious.

71 Pheysey v. Vicary (1847) 16 M. \& W. 484, 489.

72 Suffield v. Brown (1864) 4 De G. J. \& S. 185, 193.

73 H. L. Deb., 9 February 1854, vol. CXXX, 356-7.

${ }^{74}$ On this point but relating to English treatises more generally in the second half of the nineteenth century, see D. Sugarman, 'Legal Theory, the Common Law Mind and the Making of the Textbook Tradition', in W. Twining (ed.), Legal Theory and Common Law (Oxford, 1986), 26-62, at 52.

75 Jones v. Tapling (1862) 12 C.B.R. (N. S.) 829 (Toullier was cited by counsel in a case on easements); Appleby v. Myers (1867) L.R. 2 C.P. 651, 653, 655 (Duranton was cited by counsel). 


\section{Accounting for the Emergence of the English (Mis)Interpretation}

The story of this legal transplant would be incomplete without explaining how and why a separate meaning of the term 'continuous' emerged in England in the final decades of the nineteenth century. The impetus for the transformation came, initially, not from a case but from Gale's treatise. So far so unsurprising, except that it cannot be ascribed to Gale himself: the origin of the (mis)interpretation is a footnote by William Henry Willes, a barrister who composed the third edition of Gale's treatise in $1862 .{ }^{76}$ It is, though, a footnote in form rather than in substance: it runs over four pages and there is space for merely two lines of the main text on two of these four pages.

Pearson v. Spencer, in which this (mis)interpretation first appears in law, was decided just one year after the publication of the third edition of Gale's treatise. ${ }^{77}$ The reporter, in a footnote, directs the reader to the relevant pages of Willes's edition, although not specifically to his fateful footnote. Nonetheless, the influence of the footnote is plain and striking. Wilde B's statement that 'a drain may be used only occasionally' echoes Willes's contention that '[e]ven in the case of drains ... the easement is not strictly "continuous" [since] the drain is not always flowing. ${ }^{78}$ Willes's (mis)interpretation was implicitly or, at least, unconsciously endorsed in 1865 by Erle CJ in Polden v. Bastard, the case which became the leading authority for the proposition that a discontinuous easement is one which is used intermittently. ${ }^{79}$ During an unsuccessful attempt to argue that a right to take water from a well was continuous, counsel cited the precise page in Willes's edition of Gale's treatise on which the chapter on 'easements by implied grant' begins. It is, therefore, very likely that Willes's footnote, which begins in the middle of that chapter, was the source of Erle CJ's declaration that easements which are 'used from time to time' are not continuous and, thus, are not created by implication on the division of land. ${ }^{80}$

At first sight, French law seems to have played no part in the development of Willes's innovation, but a closer inspection suggests that it was

${ }^{76}$ W. H. Willes, A Treatise on the Law of Easements by C. J. Gale, 3rd edn (London, 1862).

77 (1863) 3 B. \& S. 761, 762-763 (Wilde B).

78 Willes, Easements, 104.

79 Polden v. Bastard (1865) L.R. 1 QB 156, 161; Taws v. Knowles [1891] 2 QB 564, 566 (counsel); Thomas v. Owen (1888) 20 QBD 225, 228-9 (counsel); Wood v. Waddington [2015] EWCA Civ 538, [18].

80 Willes, Easements, 103-6. 
not entirely inconsequential. One passage contains clear but indirect evidence that Willes was aware of contemporary French debates. $\mathrm{He}$ states that no 'distinction [is] drawn between drains arising by act of man, and those from natural causes, as rain water'. ${ }^{81}$ This rather esoteric point had never arisen in English law, but by 1862, when Willes's edition of Gale's treatise was published, much judicial and academic ink had already been spilled in France in pursuit of a resolution to this very question. ${ }^{82}$ Furthermore, Willes's focus on the 'act of man', a crucial element in the French definition of the term 'continuous' according to article 688 of the Civil Code, is especially revealing here, given that the rest of the footnote is devoted to the introduction of the very different criterion of frequency of use.

English law, on the other hand, is presented as the source of the novel meaning of 'continuous' which Willes proposed in the footnote. However, Glave v. Harding, the one case which is examined in detail for this purpose in the footnote, provides no support for his radical innovation. Having cited a significant portion of Bramwell B's judgment, Willes contends that it appears to be 'inconsistent' with Gale's definition of the term 'continuous' ${ }^{83}$ It is plain, however, that Bramwell B's reasoning focuses on the question of whether the easement is apparent and not whether it is continuous: his reference to the presence of 'excavations for foundations with openings, which were of a wholly uncertain character', which is reproduced in Willes's footnote, makes sense only in the context of a discussion of the question of whether the easement is apparent. ${ }^{84}$ Emptying the term 'continuous' of any content seems to have been a prelude to Willes's principal objective of recasting entirely the rule on the creation of easements by implication. Significantly, the term 'continuous' is silently dropped from Willes's alternative rule, which rests principally on Hinchcliffe v. Kinnoul, ${ }^{85}$

81 Ibid., 105.

82 See, e.g. C. Demolombe, Traité des servitudes ou services fonciers, vol. II (Paris, 1855), 217-20. This issue arose, principally, in the context of prescription, but, of course, the answer had consequences for the creation of servitudes by implication. Contrary to Willes's view, expressed in 1862, the Cour de cassation affirmed three years later that there was a distinction and that drains carrying used water were discontinuous: Cass req 19 June 1865: D.65.1.478. The claimant had expressly invoked Demolombe's argument that both types of drains were continuous.

${ }^{83}$ Willes, Easements, 104.

84 Ibid.

85 (1838) 5 Bing 1. Willes, Easements, 105-6. 
a case which, tellingly, was decided in 1838, one year before the term 'continuous' was imported into English law via Gale's treatise.

How did a footnote transform English law so dramatically? The status of Gale's treatise was, undoubtedly an important factor; as noted earlier, the prestige of the first two editions which had been composed by Gale himself was, seemingly seamlessly, extended to subsequent editions which were produced by others. ${ }^{86}$ Moreover, Willes's edition of Gale's treatise was also considered to be of particular importance. This footnote in Willes's edition was not the only one which was given unusual prominence in English law: in Wheeldon v. Burrows, a separate and much shorter footnote by Willes is invoked by counsel on both sides. ${ }^{87}$ It is especially notable that one argument in that case even relied on the precise date on which this footnote was published. ${ }^{88}$ Thus, as the author of the sixth edition of Gale's treatise noted, 'Mr. Willes' observations ... have often been quoted as authority'. ${ }^{89}$

Willes's footnote on the meaning of the term 'continuous' was significant because it categorically contradicted the main text. There is an oblique acknowledgement of this inconsistency, but it is dismissed peremptorily and unconvincingly on the ground that it 'is only apparent'. ${ }^{90}$ Willes's footnote was consistently given more prominence as each edition of Gale's treatise succeeded another; subsequent authors were, therefore, consciously or unconsciously complicit in Willes's endeavour to circumvent the French interpretation of the term 'continuous'. In all editions from the fourth, in 1868, to the twelfth, in 1950, the label 'Mr Willes's opinion' was added to the margin. ${ }^{91}$ Moreover, from 1888 , Willes's views became even more conspicuous. In the edition of Gale's treatise which was published in that year, the footnote was upgraded to the main text,

${ }^{86}$ See the text from n. 75 to $n .76$.

87 (1879) 12 Ch D 31, 35, 36, 37. The reference is to a footnote on the creation of easements by implication in favour of the grantor in the edition of Gale's treatise which, at that point, had been published most recently: D. Gibbons, A Treatise on the Law of Easements: With the Notes of W. H. Willes, 5th edn (London, 1876), 102-3.

88 (1879) 12 Ch D 31, 36.

89 G. Cave, A Treatise on the Law of Easements: With the Notes of W. H. Willes, 6th edn (London, 1888), iii-iv.

90 Willes, Easements, 104.

${ }^{91}$ In contrast to previous authors who had retained the structure of the first edition of Gale's treatise, Bowles, who published the thirteenth edition in 1959, deliberately reorganised the treatise on the ground that it had 'come to acquire a certain disjointedness and inconclusiveness'; Bowles, Gale on Easements, viii. 
although it was still placed in square brackets. ${ }^{92}$ Willes's ideas finally broke free from all these textual restraints in 1916 when they were inserted in the main text of the treatise. ${ }^{93}$ Yet, the contradiction was then even more patent. Indeed, it also emerged elsewhere in this edition of the treatise. In the first twelve editions of Gale's treatise, the terms 'continuous' and 'discontinuous' were expressly defined in a preliminary chapter by reference to article 688 of the Civil Code, but, in this 1916 edition, the English (mis)interpretation was added, incongruously, as a footnote without any express recognition of a contradiction. ${ }^{94}$

The treatise was altered radically in 1959. The author of the thirteenth edition, which was published in that year, removed the definitions of the terms 'continuous' and 'discontinuous' which had featured in the early chapters of all previous editions; indeed, he removed all references to French law and Roman law on the ground that they are 'not now likely to influence the decision on any new point'. ${ }^{95}$ The text of 'Willes's opinion' was also discarded at this point. As the author of this edition noted pungently in the preface, the chapter in which this section appeared was 'confused to the last degree ... [and] in places ... barely intelligible'. ${ }^{96}$ Thus, from 1863, when Willes's edition was published, until 1959, Gale's treatise could be and, as we have seen, was invoked to support two entirely contradictory interpretations of the term 'continuous'. ${ }^{97}$

\section{Three Lessons for Comparative Law and Legal History}

Drawing together the different threads of the story yields three significant insights of a comparative and historical nature. The first relates to legal transplants; the final two concern the sources of English law.

As for legal transplants, it seems that there may be, alongside the contested presumption of similarity, an unarticulated presumption of suitability in comparative law with respect to the rule in the donor system. ${ }^{98}$ Thus, when a transplanted rule is not suited to the donee

92 Cave, Easements, 108-12.

93 T. H. Carson, A Treatise on the Law of Easements by Charles James Gale, 9th edn (London, 1916), 135-9.

94 Ibid., 29-30.

95 Bowles, Gale on Easements, ix.

96 Ibid., viii.

97 See the text from n. 40 . to n. 51 .

98 Such a presumption is not limited to one side in the debate on legal transplants. See, e.g. A. Watson, Legal Transplants: An Approach to Comparative Law (Edinburgh, 
system, the social, cultural, political, economic and legal context of that forum are frequently examined minutely in the pursuit of explanations for the failure. The great comparative lawyer, Montesquieu, stated that laws 'should be so appropriate for the people for whom they are made that it is a very great coincidence if those of one nation are capable of suiting another'; ${ }^{\prime 99}$ significantly, his premise was not that laws are always appropriate for the people for whom they are made. The story of the rule on 'continuous' servitudes shows that looking backwards at the donor system can be especially illuminating: it has revealed that the rule was unsuitable in the donor system before it migrated to the donee system.

One might call such a rule a 'legal irritant', extending a familiar idea in comparative law to the rule in the donor system too. ${ }^{100}$ However, casting one's gaze further afield and borrowing from sociology, where the theory and method of functional analysis has been examined with rigour, produces more incisive insights into the rule on 'continuous' servitudes. In the language of the fecund model devised by Robert Merton, it is clear that this rule has always been 'dysfunctional' in both systems. ${ }^{101}$ Neither the English nor the French varieties have ever had any discernible purpose. ${ }^{102}$ Furthermore, the logical consequences of the application of the rule as originally formulated in the Civil Code were resisted in both systems: the French and English versions have been modified, in substance but not in form, to include almost all servitudes and easements respectively. Thus, as Merton's model predicts, in both systems, the 'stress, strain and tension' caused by the dysfunctional consequences ultimately led to changes which made the rule less dysfunctional. ${ }^{103}$ Therefore, a transplanted rule may be dysfunctional not because it is

1974); although the converse view appears in A. Watson, Society and Legal Change, 2nd edn (Philadelphia, 2001), 99; P. Legrand, Pour la relevance des droits étrangers (Paris, 2014).

99 C.-L. de S., de Montesquieu, De l'esprit des loix, vol. I (Geneva, 1748), 10. Montesquieu uses the verb 'devoir', which could mean 'must' rather than 'should', but the latter interpretation is more plausible given the context.

100 Teubner, 'Legal Irritants'.

101 R. Merton, On Theoretical Sociology: Five Essays, Old and New (New York and London, 1967), 73-138. I am grateful to Professor Mitchel Lasser for drawing my attention to Merton's work on functionalism.

102 Consequently, it is clear that it is not a 'malicious' transplant in the sense in which Siems has used that term; M. Siems, 'Malicious Legal Transplants', Legal Studies, 38 (2018), 103-19. I am grateful to Professor Paula Giliker for drawing my attention to this article.

103 Merton, Theoretical Sociology, 107. Notwithstanding the reduction of dysfunctional consequences, some, arguably, remain. However, this question calls for a critical examination of the modern law; it is, thus, outside the scope of a historical study. 
not suited to conditions in the donee system but because it is dysfunctional in every place and in every time. The inception of the rule on 'continuous' servitudes in France in 1804 and its trajectory thereafter in both France and England indicates that it is such a rule: it was dysfunctional ab initio.

The second lesson concerns the significance of the French Civil Code as a source of English law. Harry Lawson, who once held the chair of comparative law at Oxford, said that he was 'certain' that the Civil Code had never influenced English law, and he added, emphatically, that ' $[\mathrm{i}] \mathrm{t}$ would be [a] sheer waste of time to look for any such thing. ${ }^{104}$ Although, the Civil Code has, unquestionably been less influential than certain French treatises, ${ }^{105}$ Lawson's claim is far too sweeping. It is clear, for example, that the Civil Code formed an important part of the reasoning in Hadley v. Baxendale, a foundational case from 1854 on the measure of damages in English contract law. ${ }^{106}$ Furthermore, the Civil Code was one of the factors which inspired the momentum for reform in land law in the first half of the nineteenth century. It featured prominently in several parts of the famous speech delivered by Henry Brougham in the House of Commons in 1828; perhaps most notably, the strong connection between the Civil Code and Napoleon was used to great effect in the conclusion, when members were exhorted to '[o] utstrip him as a lawgiver, whom in arms [they] overcame!'. ${ }^{107}$ Thus, even before reverting to the rule on 'continuous' easements, which, unquestionably came from 'the French Code Civil', ${ }^{108}$ it is plain that Lawson's claim can be refuted. However, his claim appears to be even more unsustainable now that the comparative and historical context of the rule on 'continuous' easements has been unravelled and reconstructed. In terms of longevity and enduring controversy, there seems to be no comparable example in English law to this transplantation from the Civil Code. ${ }^{109}$ Perhaps only the reception of Pothier's views on mistake of identity in contract law comes close. ${ }^{110}$

104 F. H. Lawson, The Comparison: Selected Essays, vol. 2 (Amsterdam, 1977), 39.

105 On the latter, see n. 6.

106 (1854) 9 Ex. 341, 347 (Parke B).

107 H. C. Deb., 7 February 1828, vol. XVIII, 246.

108 Suffield v. Brown (1864) 4 De G. J. \& S. 185, 193 (Lord Westbury LC).

109 As the litigation in Wood v. Waddington [2015] EWCA Civ 538 demonstrates, the meaning of 'continuous' is still contested.

110 The most recent episode is Shogun Finance Ltd v. Hudson [2004] 1 AC 919, 948 (Lord Millett). For a succinct overview of the history of this controversy, see J. Cartwright, Misrepresentation, Mistake and Non-Disclosure, 5th edn (London, 2019), 503-4. 
The role of English treatises as sources of law in England is the subject of the final lesson. An English treatise played the principal role in the transplantation of the rule on 'continuous' easements: the importation and marketing of the plant, to continue the metaphor, was undertaken by Gale and the authors who published several subsequent editions of his treatise. Significantly, counsel and judges relied on Gale's treatise rather than the Civil Code itself. Even where the text of the French provisions is examined, the source is Gale's translation and not the Civil Code itself. ${ }^{111}$ An important nuance must, therefore, be added to the position outlined in the preceding paragraph: the source of the English rule is the French Civil Code via Gale's treatise. This finding is wholly unsurprising: almost half a century ago, Simpson showed that English treatises were responsible for the propagation of French legal ideas on contract law in the English courts. ${ }^{112}$ It is now clear that this phenomenon was not limited to contract law and that the survival of the rule on 'continuous' easements can be ascribed not just to Gale but to the authors who preserved his legacy in later editions of the treatise.

Conversely, a focus on English treatises as sources of English law leads to a separate finding which is wholly surprising. It is generally thought that, in the nineteenth century, these treatises were centripetal rather than centrifugal forces: they presented 'a chaotic common law' as consistent by marginalising or even omitting evidence to the contrary. ${ }^{113}$ However, the various editions of Gale's treatise which are discussed in this chapter do not fit this model. In sharp contrast to other treatises, Gale's, with Willes's additions, were a cause of inconsistency. This inconsistency subsequently leaked into the cases, contaminating the law, since counsel and judges relied heavily on this secondary source. The problem was compounded by the reluctance of subsequent authors to alter the text until 1959, when, in the thirteenth edition, the contradictions were finally expunged.

\section{Conclusion}

To return to Orwell's Nineteen Eighty-Four, it seems that the clock strikes thirteen in both England and France: the English rule on 'continuous'

111 Pheysey v. Vicary (1847) 16 M. \& W. 484, 489 (counsel).

112 Simpson, 'Innovation'.

113 Sugarman, 'The Textbook Tradition', 54. Simpson's thesis, while different, is not wholly inconsistent with that of Sugarman. The former argues that, before the advent of treatises, 'it is certainly not always easy to identify and formulate the doctrine that is latent in the sources'; Simpson, 'Innovation', 251. 
easements seems peculiar even when encountered independently of its French progenitor, and the reverse is also true. Nonetheless, the clock chimes even louder when the full historical and comparative dimensions of these rules are exposed. Neither the French interpretation nor the English (mis)interpretation of the terms continuous and discontinuous have an obviously rational justification, and it is not clear why discontinuous servitudes, however defined, should be excluded from the rule on the creation of servitudes by implication. The fact that both the English and French varieties are now almost obsolescent in practice demonstrates that the exclusion of certain servitudes was, plainly, considered to be undesirable in both systems; this conclusion is reinforced by the fact that the mutation of each rule in this direction occurred entirely independently of that of the other. 